\title{
Identification and functional importance of plasma kallikrein in the synovial fluids of patients with rheumatoid, psoriatic, and osteoarthritis
}

\author{
M M Rahman, K D Bhoola, C J Elson, M Lemon, P A Dieppe
}

Department of Pharmacology, University of Bristol, Bristol,

United Kingdom

M M Rahman

Department of

Pathology

C J Elson

Department of

Chemical Pathology

M Lemon

Department of

Rheumatology

P A Dieppe

Department of

Experimental and

Clinical Pharmacology,

Medical School,

University of Natal,

South Africa

K D Bhoola

Correspondence to:

Professor K D Bhoola,

Department of Experimental

and Clinical Pharmacology,

Medical School,

University of Natal

P O Box 17039,

Congella 4013,

Durban, South Africa.

Accepted for publication

9 January 1995

\begin{abstract}
Objectives-To determine and identify, unequivocally, if plasma kallikrein (PK) is present in the synovial fluid of patients with rheumatoid (RA), psoriatic (PA) and osteo (OA) arthritis, and to consider its functional importance in the inflamed joint.
\end{abstract}

Methods-Therapeutically aspirated synovial fluids (pooled and individual samples, $n=66$ ) were obtained from patients with arthritis. In addition, serum $(n=14)$ was collected from $R A$ patients, and saliva $(n=10)$ and urine $(n=10)$ from normal individuals. Enzymic (amidase) and immunoreactive activities of $P K$ and its precursor, prokallikrein (PPK), were determined. The presence of $P K$ was assessed by incubation with soya bean trypsin inhibitor (SBTI), and by adsorption with anti-PK antibody linked to Sepharose. An enzyme-linked immunosorbant assay (ELISA) for PK was developed for quantitative measurement of total PK in biological fluids. Enhancement of the PK dose-response by RA synovial fluid made it necessary to remove RF from synovial fluids before determination of PK by ELISA.

Results-Amidase activity was demonstrated in synovial fluid pools and shown to be inhibited completely by SBTI, and removed by prior treatment with anti-PK Sepharose. Total PK activity (PK + PPK) from individual synovial fluid specimens did not differ significantly between patients with RA (median activity $76 \mathrm{mU} / \mathrm{g}$ protein), PA (80 $\mathrm{mU} / \mathrm{g}$ protein) or OA (60 $\mathrm{mU} / \mathrm{g}$ protein). Similar results were obtained when active PK alone was measured. No correlation was found between active PK or total PK values and the severity score for individual joints. Most of the measured immunoreactivity was removed by adsorption with anti-PK antibody linked to Sepharose.

Conclusions-The results support the hypothesis that plasma kallikrein is present in synovial fluid. The enzyme may be important in the pathogenesis of inflamed joints.

\section{(Ann Rheum Dis 1995; 54: 345-350}

Kinins are vasoactive peptides that cause constriction of venules, dilatation of arterioles, and increased permeability of capillary membranes, and interact with sensory nerve terminal transmitters to evoke pain. They are formed by the cleavage of $\mathrm{H}$ - and L- kininogens by serine proteases known as kallikreins (plasma and tissue), which occur in various biological fluids, tissues, and cells. ${ }^{1}$ It has been proposed that the pain and swelling in inflammatory joint disease may be mediated by kinins, and the evidence in support of this view has been reviewed elsewhere. ${ }^{2}$

We have previously identified tissue kallikrein in synovial fluid of patients with inflamed joints, particularly patients with rheumatoid arthritis (RA), and thus established the presence of one of the two major kinin forming enzymes (kininogenases) in arthritic joints. ${ }^{3}$ Plasma kallikrein (PK) was first implicated in gout by Kellermeyer and Breckenridge. ${ }^{4}$ Although PK has been demonstrated to occur in the synovial fluid (SF) of patients with $\mathrm{RA},{ }^{5}{ }^{6}$ the amidase activity present has not been shown to be attributable exclusively to this enzyme. The purpose of the present study was to examine critically and identify levels of enzymic and immunoreactive $\mathrm{PK}$, to enable their determination in the SF of patients with inflamed joints.

Patients, samples and methods

PATIENTS

Knee joint SF was collected from randomly selected patients with diagnoses of RA (pooled $\mathrm{n}=14$; individual $\mathrm{n}=15$ ), osteoarthritis (OA) (pooled $n=13$; individual $n=8$ ) and psoriatic arthritis (PA) (pooled $n=11$; individual $n=8$ ), attending the Rheumatology Unit of Bristol Royal Infirmary (BRI) (table 1). The severity of joint inflammation was assessed clinically at the time of the SF aspiration, and was based on the degree of swelling, joint tenderness, local temperature, and erythema.

\section{SAMPLES}

Synovial fluid-Therapeutically aspirated SF from the knee joint was centrifuged at $3000 \mathrm{~g}$ for 10 minutes at room temperature. The volume of SF aspirated varied with each patient (table 1). After centrifugation the supernatants were thoroughly mixed, and $1 \mathrm{ml}$ aliquots stored at $-20^{\circ} \mathrm{C}$. To reduce viscosity, before assay the samples were treated with $22.5 \mathrm{IU} / \mathrm{ml}$ of hyaluronidase (Sigma Chemicals) for 30 minutes at $37^{\circ} \mathrm{C}$, and subsequently 
Table 1 Clinical details of pooled and individual synovial fluid samples from patients with $R A, P A$, or $O A$

\begin{tabular}{|c|c|c|c|c|c|c|}
\hline & \multicolumn{3}{|c|}{ Pooled samples } & \multicolumn{3}{|c|}{ Individual samples } \\
\hline & $R A$ & $P A$ & $O A$ & $R A$ & $P A$ & $O A$ \\
\hline $\begin{array}{l}\text { No of patients } \\
\text { Male } \\
\text { Female } \\
\text { Age (yr) }\end{array}$ & $\begin{array}{l}14 \\
4 \\
10 \\
60(27-80)\end{array}$ & $\begin{array}{l}11 \\
10 \\
11 \\
43(24-73)\end{array}$ & $\begin{array}{l}13 \\
2 \\
11 \\
70(54-83)\end{array}$ & $\begin{array}{l}15 \\
2 \\
13 \\
67(44-88)\end{array}$ & $\begin{array}{r}8 \\
7 \\
1 \\
41(24-73)\end{array}$ & $\begin{array}{l}5 \\
1 \\
4 \\
70(54-83)\end{array}$ \\
\hline $\begin{array}{l}\text { Duration of disease }(\mathrm{yr}) \\
<2 \\
2-10 \\
>10\end{array}$ & $\begin{array}{r}1 \\
3 \\
10\end{array}$ & $\begin{array}{l}3 \\
4 \\
4\end{array}$ & $\begin{array}{l}2 \\
5 \\
6\end{array}$ & $\begin{array}{r}0 \\
5 \\
10\end{array}$ & $\begin{array}{l}2 \\
3 \\
3\end{array}$ & $\begin{array}{l}0 \\
2 \\
3\end{array}$ \\
\hline $\begin{array}{l}\text { Symptoms } \\
\text { Severe } \\
\text { Mild/moderate } \\
\text { None }\end{array}$ & $\begin{array}{l}6 \\
8 \\
0\end{array}$ & $\begin{array}{l}3 \\
6 \\
2\end{array}$ & $\begin{array}{r}2 \\
11 \\
0\end{array}$ & $\begin{array}{r}10 \\
5 \\
0\end{array}$ & $\begin{array}{l}1 \\
5 \\
2\end{array}$ & $\begin{array}{l}1 \\
4 \\
0\end{array}$ \\
\hline Aspiration volume (ml) & $31(5-90)$ & $168(10-550)$ & $17(2-55)$ & $25(10-73)$ & $213(10-550)$ & $25(15-50)$ \\
\hline
\end{tabular}

Values are numbers, or mean (range).

centrifuged at $3000 \mathrm{~g}$ for 10 minutes at room temperature.

Serum-Blood samples obtained from $14 \mathrm{RA}$ patients attending the Rheumatology Unit at $\mathrm{BRI}$ were centrifuged at $180 \mathrm{~g}$ for 10 minutes. The supernatants were pooled and aliquots stored at $-20^{\circ} \mathrm{C}$. Before assay the samples were re-centrifuged at $3000 \mathrm{~g}$ for 10 minutes at room temperature.

Urine-Urine samples, collected from 10 healthy subjects attending the Nephrology Unit of Southmead Hospital Bristol (SHB) were pooled and aliquots stored at $-70^{\circ} \mathrm{C}$. Before measurement, each sample was centrifuged at $3000 \mathrm{~g}$ for 10 minutes.

Saliva-Saliva, obtained from healthy subjects attending the Nephrology Unit of SHB, was pooled and aliquots immediately frozen and stored at $-70^{\circ} \mathrm{C}$. Before measurement, each sample was centrifuged at $3000 \mathrm{~g}$ for 10 minutes.

AMIDASE ACTIVITY OF PK

Because the enzymic activity of $\mathrm{PK}$ in biological fluids is believed to be regulated mainly by $\mathrm{Cl}$ inhibitor and $\alpha_{2}$-macroglobulin, ${ }^{78}$ samples were denatured with an equal volume of $0.167 \mathrm{~mol} / 1 \mathrm{HCl}(\mathrm{pH} 1 \cdot 0) .{ }^{9}$

To measure the total amidase activity of PK and its precursor, prokallikrein (PPK), we used the selective synthetic chromogen, H-D-ProPhe-Arg-pNA (S2302; Kabivitrum, Sweden). ${ }^{10}$ The assay method was adapted from that described by De La Cadena et al, ${ }^{11}$ using wells on microtitre plates as reaction sites for measurement of PK + PPK. Samples $(50 \mu \mathrm{l})$ were incubated with $50 \mu \mathrm{l}$ of $0.167 \mathrm{~mol} / 1 \mathrm{HCl}$ $(\mathrm{pH} 1.0)$ for 25 minutes at room temperature, then $50 \mu \mathrm{l}$ of buffer $(0.1 \mathrm{mmol} / \mathrm{l}$ sodium phosphate buffer in $0.15 \mathrm{mmol} / 1 \mathrm{NaCl}$ and $1 \mathrm{mmol} / \mathrm{l}$ EDTA, $\mathrm{pH} 7 \cdot 6$ ) was added to the mixture. Finally, the $\mathrm{pH}$ of the reaction mixture was adjusted to $7 \cdot 4$ with $50 \mu l$ of $0 \cdot 167 \mathrm{~mol} / \mathrm{l} \mathrm{NaOH}$.

Standard curves were generated with purified PPK (Protogen, Switzerland). PPK $(66.67 \mu \mathrm{g})$ was dissolved in $1 \mathrm{ml}$ of assay buffer $(0.1 \%$ polyethylene glycol in $0.05 \mathrm{~mol} / 1$ Tris-

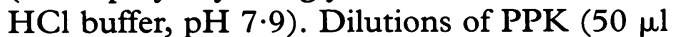
per well) were added to the wells of the microtitre plate; similarly, blanks prepared with assay buffer were added to designated wells. Next, $50 \mu \mathrm{l}$ of the PPK activation mixture $(25 \mu \mathrm{g} / \mathrm{ml}$ mixture of H-kininogen and L-kininogen, gift from Professor Werner Müller-Esterl, University of Mainz; $5 \mu \mathrm{g} / \mathrm{ml}$ Factor XIIa, Nova Biochem; $0 \cdot 1 \mathrm{~mol} / \mathrm{l}$ ellagic acid, Sigma Chemicals and $1 \mu \mathrm{g} / \mathrm{ml}$ l- $\alpha$-phosphatidylethanolamine, Sigma Chemicals) was added, and the plate incubated for 15 minutes at $37^{\circ} \mathrm{C}$. Finally, for the measurement of the activated PPK and the PK in the SF samples, $50 \mu$ l of substrate (S2302) was added to each well, the plate incubated for a further 30 minutes at $37^{\circ} \mathrm{C}$, and the absorbance read in a BioRad mictrotitre plate reader at $405 \mathrm{~nm}$. Hydrolysis of $1 \mu \mathrm{mol}$ of substrate (S2302) per minute equalled $1 \mathrm{mU}$.

Specificity of the amidase activity of $P K-$ The specificity of the synovial fluid PK amidase activity was examined with the selective enzyme inhibitor, soya bean trypsin inhibitor (SBTI). ${ }^{12}$ SF samples were incubated for 30 minutes at $37^{\circ} \mathrm{C}$ with SBTI $(300 \mu \mathrm{g}$ of a solution of $1 \mathrm{mg} / \mathrm{ml}$ ) before the addition of substrate (S2302). As a further test of specificity, SF samples were also adsorbed with anti-PK Sepharose to remove PK + PPK before incubation with the substrate.

Units of PK amidase activity-Non-specific absorbance attributable to the samples was obtained by incubating them in the absence of substrate; assay values were corrected for the non-specific absorbance. PK activity in the test samples was determined by reference to a simultaneously measured standard curve using purified PK, and amidase activity expressed as $\mathrm{mU} / \mathrm{g}$ protein. The protein concentration of samples was measured as described by Bradford. ${ }^{13}$

MEASUREMENT OF PK + PPK

Removal of rheumatoid factor from synovial fluid-Once the concentration dependency of purified PK was determined and optimised, the influence of RA synovial fluid (diluted $1: 200$ ) on PK immunoreactivity (examined by spiking the PK standard curve) showed marked enhancement of the PK dose-reponse curve when a constant amount of diluted RA synovial fluid was added to each PK standard. It was considered that this effect was probably 
1) Coating antigen $\mathrm{PK} 1: 35$ $(1.91 \mu \mathrm{g} / \mathrm{ml})$

2) Incubation with blocker (5\% Marvel-Tris- $\mathrm{NaCl}$ ) (standard)/sample with anti-PK rabbit lgG $15 \mu \mathrm{g} / \mathrm{ml}$

4) Adding the preincubated PK standard/sample to congugate 1:1000

6) Extravadin-alkaline phosphatase 1:250

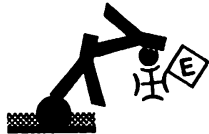

7) Disodium p-nitrophenyl phosphate (substrate) $1 \mathrm{mg} / \mathrm{ml}$
3) Preincubation of PK the ELISA plate

5) Anti-rabbit lgG biotin

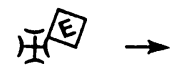

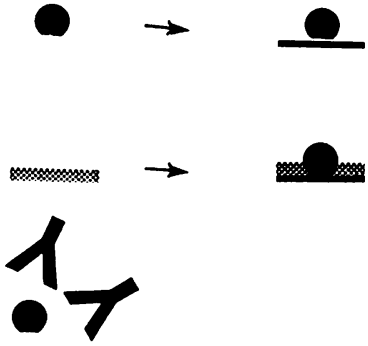
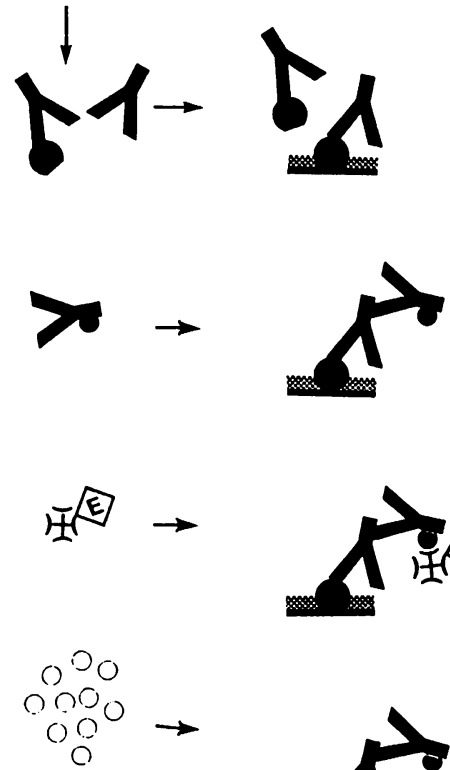

blank wells. The plates were incubated for one hour at $37^{\circ} \mathrm{C}$. Unoccupied sites were blocked by incubation for 30 minutes at room temperature with $100 \mu \mathrm{l}$ per well of $5 \%$ fat free bovine milk (Marvel) in $0.02 \mathrm{~mol} / \mathrm{l}$ Tris, $0 \cdot 14 \mathrm{~mol} / 1 \mathrm{NaCl}$ and $0 \cdot 05 \%$ Tween $20, \mathrm{pH} 7 \cdot 2$. Next, each SF sample of PK dose (in 5\% Marvel) was incubated with $15 \mu \mathrm{g} / \mathrm{ml}$ of purified anti-PK rabbit IgG (Nova Biochem, Switzerland) at $37^{\circ} \mathrm{C}$ for one hour. The mixture $(100 \mu \mathrm{l})$ was added to the wells and the plate incubated for one hour at $37^{\circ} \mathrm{C}$. Thereafter, the plate was incubated sequentially with $1: 1000$ anti-rabbit $\operatorname{IgG}$ biotin conjugate (Sigma Chemicals) and 1:250 extravidin alkaline phosphatase (Sigma Chemicals) for one hour each at $37^{\circ} \mathrm{C}$. The wells were washed with phosphate buffered saline containing $0 \cdot 1 \%$ Tween 20 , three times between each step. The final incubation was performed with disodium $p$-nitrophenyl phosphate $(1 \mathrm{mg} / \mathrm{ml}$, Sigma Chemicals) for one hour at $24^{\circ} \mathrm{C}$, and absorbancies read at $405 \mathrm{~nm}$ in a BioRad (UK) Colorimetric plate reader. Absorbance values for the samples and standard curves were corrected by subtracting the non-specific absorbance (blanks). The immunoassay measured both PK and PPK because the antibody does not discriminate between the two molecular species.

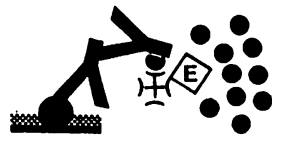

Figure 1 Schematic representation of the stages involved in the PK ELISA method using an avidin-biotin system. E = alkaline phosphatase. Steps 1, 3, 4, 5, and 6: Microtitre plate incubated for one hour at $37^{\circ} \mathrm{C}$. Step 2: Microtitre plate incubated for 30 minutes at room temperature. Step 6: Microtitre plate incubated for one hour at $24^{\circ} \mathrm{C}$. After each step the plate was washed with PBS-Tween 20 (three times for 10 seconds).

the result of a combination of $\mathrm{PK}$ and rheumatoid factor (RF) present in SF. Therefore, as part of routine sample preparation $\mathrm{RF}$ was removed from SF samples before the measurement of PK immunoreactivity in SF. Samples of SF were incubated with 0.3 volumes of heat aggregated rabbit IgG coupled to cyanogen bromide Sepharose and 0.2 volumes of $0.1 \mathrm{~mol} / 1 \mathrm{Tris} / 0.5 \mathrm{~mol} / 1 \mathrm{NaCl}$ $(\mathrm{pH} 8 \cdot 5)$ for 30 minutes at room temperature. Enzyme linked immunosorbent assay (ELISA)Figure 1 illustrates the method for PK immunoassay. To coat microtitre plates with human PK, a stock solution, prepared at a concentration of $66.67 \mu \mathrm{g} / \mathrm{ml}$ in bicarbonate buffer $\left(15 \mathrm{mmol} / 1 \quad \mathrm{Na}_{2} \mathrm{CO}_{3}, 35 \mathrm{mmol} / \mathrm{l}\right.$ $\mathrm{NaHCO}_{3}, \mathrm{pH} 9 \cdot 6$ ), was diluted and applied to the wells at a concentration of $1.91 \mu \mathrm{g} / \mathrm{ml}$; bicarbonate buffer alone was added to the

Table 2 Amidase activity of $P K$ in pooled samples of $R A(n=14), P A(n=11)$, and $O A$ $(n=13)$ synovial fluid and $R A$ serum $(n=14)$

\begin{tabular}{|c|c|c|c|c|c|c|}
\hline \multirow[t]{2}{*}{ Biological fluid } & \multicolumn{6}{|c|}{ Activity ( $m U / g$ protein) } \\
\hline & \multicolumn{3}{|l|}{ Active PK } & \multicolumn{3}{|l|}{$P P K$} \\
\hline RA synovial fluid & $28(1 \cdot 4)$ & \multirow{4}{*}{$\begin{array}{l}p= \\
0.033 \\
p= \\
0.055\end{array}$} & \multirow{4}{*}{$\begin{array}{l}p= \\
0.011\end{array}$} & $65(1 \cdot 6)$ & $p=$ & \multirow{3}{*}{$\begin{array}{l}p= \\
0.398\end{array}$} \\
\hline PA synovial fluid & $13(0 \cdot 4)$ & & & $22(0 \cdot 5)$ & & \\
\hline OA synovial fluid & $3(0.5)$ & & & $71(1 \cdot 1)$ & 0.001 & \\
\hline RA serum & $43(1 \cdot 3)$ & & & $70(1 \cdot 7)$ & & \\
\hline
\end{tabular}

Values are mean (SEM).
STATISTICAL ANALYSIS

Significance was determined by analysis of variance.

\section{Terminology}

Throughout this paper, $\mathrm{PK}=$ active plasma kallikrein, PPK = pre-plasma kallikrein (the plasma kallikrein precursor), and $\mathrm{PK}+\mathrm{PPK}=$ total $\mathrm{PK}$ after activation of PPK.

\section{Results}

AMIDASE ACTIVITY

To determine the amounts of PK and PPK in synovial fluids, as a first step the relationship between amidase activity and PK concentration was examined. As the amidase activity increased linearly up to a PK concentration of $4.4 \mu \mathrm{g} / \mathrm{ml}$, all samples were diluted to give an activity below this value.

The amidase activity of the pooled SF samples was measured before and after activation of PPK in order to investigate the amount of active PK relative to the total PK (PPK + active PK). The proportion of the total PK present as active PK was $43 \%, 59 \%$ and $4 \cdot 2 \%$ for RA, PA and OA pools, respectively (table 2). Median values for active PK were: RA $27 \mathrm{mU} / \mathrm{g}$ of protein, PA $20 \mathrm{mU} / \mathrm{g}$ of protein, and OA $20 \mathrm{mU} / \mathrm{g}$ of protein (fig 2); those for PK + PPK were: RA $76 \mathrm{mU} / \mathrm{g}$ of protein, PA $80 \mathrm{mU} / \mathrm{g}$ of protein, and $\mathrm{OA}$ $60 \mathrm{mU} / \mathrm{g}$ of protein (fig 3). These differences between RA, PA and OA SF samples did not reach statistical significance $(p>0.05)$, and comparisons of clinical scoring showed no clear correlation with PK activity. 


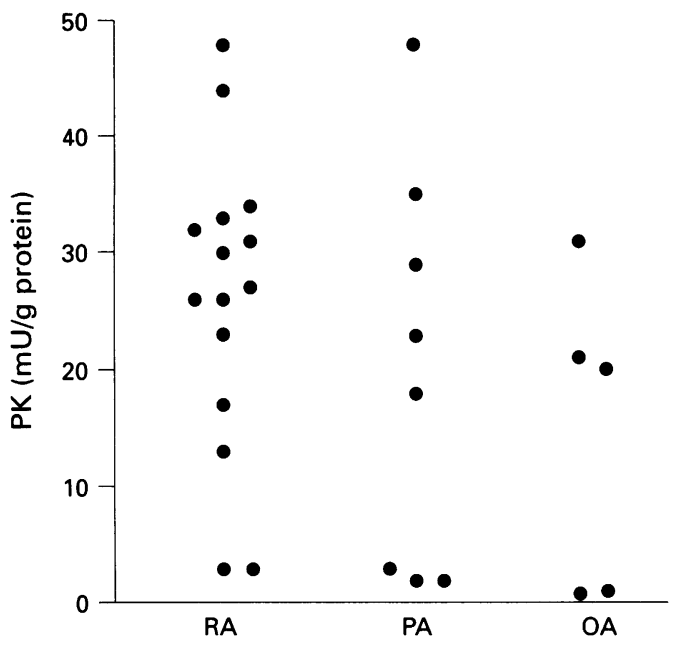

Figure 2 PK amidase activity of individual synovial fluid samples of patients with $R A, P A$, and $O A$. Each measurement was performed in duplicate.

Comparison of PK and PPK values for the RA SF and serum pool samples showed greater values for both enzyme forms in serum than in SF (table 2). No PK + PPK activity was detectable in saliva or urine using the selective substrate $\mathrm{S} 2303$ ( $<0.05 \mathrm{mU} / \mathrm{g}$ protein).

As shown in table 3, the enzymic activity of $\mathrm{PK}+\mathrm{PPK}$ in the RA, PA, and OA pooled SF samples was almost completely inhibited by the addition of SBTI. In the experiments in which PK + PPK were removed from the pooled SF samples by absorption with anti-PK Sepharose before incubation with substrate, absorption of both PK and PPK by the antibody from each SF pool was even greater than the inhibition by SBTI (table 3).

\section{IMMUNOREACTIVE PLASMA KALLIKREIN}

Figure 4 illustrates the marked enhancement of the PK dose-response curve when a constant amount of diluted RA synovial fluid was added to each PK standard-an effect believed to be due to a combination of PK and RF present in SF. Routine preparation of SF samples therefore included removal of RF before measurement of PK immunoreactivity in SF. Most of the immunoreactive $\mathrm{PK}$ in $\mathrm{RF}$ depleted

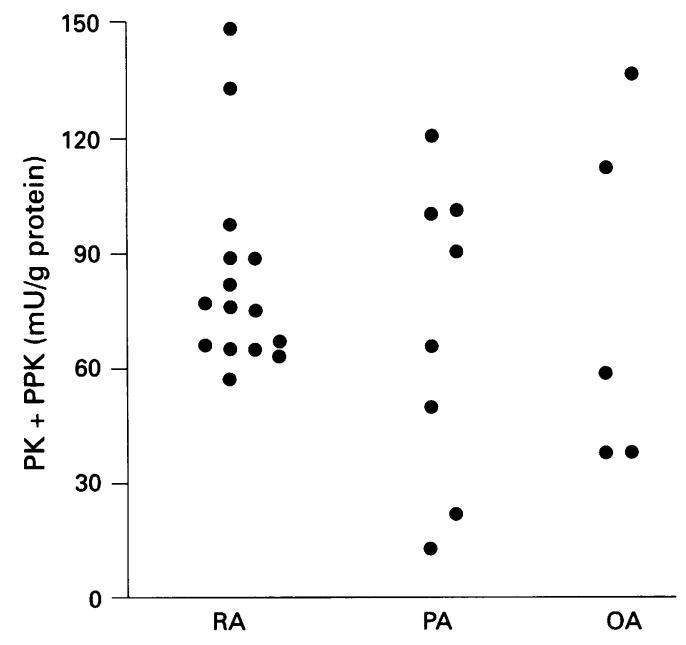

Figure $3 \quad P K+P P K$ amidase activity of individual synovial fluid samples of patients with $R A, P A$, and $O A$. Each measurement was performed in duplicate.
Table 3 Percentage inhibition by SBTI and removal by anti-PK Sepharose (anti-PKS) of both PK and PPK amidase activity from $R A, P A$, and $O A$ synovial fluids

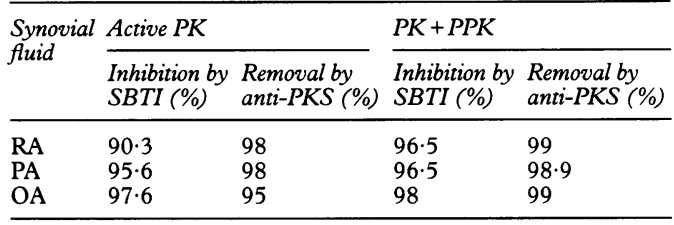

samples was removed by anti-PK Sepharose (table 3), but there remained a residual immunoreactivity $(32 \%, 28 \%$, and $48 \%$ for RA, PA and OA, respectively) which could be attributable to residual RF in the SF samples. When immunoreactive PK was determined in the pooled SF samples, similar levels were observed in RA $(4.7$ (SEM 0.5$) \mu \mathrm{g} / \mathrm{mg}$ protein), PA (6.5 (0.7) $\mu \mathrm{g} / \mathrm{mg}$ protein) and OA $(5.0 \quad(0.7) \mu \mathrm{g} / \mathrm{mg}$ protein) synovial fluids (fig 5). As with amidase activity, no immunoreactive $\mathrm{PK}+\mathrm{PPK}$ was measured in saliva or urine.

\section{Discussion}

This study has identified PK $+\mathrm{PPK}$ in the synovial fluids taken from the knee of patients with arthritis. Because of the relatively small numbers of individual samples we cannot draw any definite conclusions about the contribution of plasma kallikrein to the clinical features of these arthropathies, but, while earlier reports had shown the occurrence of PK in the SF of RA patients, we have achieved the first precise measurements of the amidase activity attributable to $\mathrm{PK}$ in the inflamed joints. We chose two primary methods to determine the concentration of $\mathrm{PK}$ in the synovial fluids: measurement of PK functional activity by microassay on the selective peptide substrate, H-D-ProPhe-Arg-pNA, and PK immunoreactivity by ELISA. The identification and verification of PK + PPK amidase activity was performed on $\mathrm{SF}$ pools, but in order to determine the range of activity, individual SF samples were examined for PK + PPK amidase activity.

Various evidence suggests that the amidase activity measured in SF reflected true plasma kallikrein values. First, the PK + PPK amidase activity was inhibited by SBTI (PK is completely inhibited by SBTI).$^{12}$ Second, the amidase activity was removed with anti-PK Sepharose. Finally, saliva and urine (which contain considerable amounts of tissue kalli$k \operatorname{rin}^{14}{ }^{15}$ ) failed to hydrolyse the selective PK + PPK substrate (H-D-Pro-Phe-ArgpNA). Therefore, the amidase activity of the RA, PA, and OA synovial fluids on this selective substrate was attributable to $\mathrm{PK}$ (intrinsic activity) and PPK (increase in activity after activation).

This study is the first to report immunoreactive PK in synovial fluids using an ELISA. RA synovial fluid enhanced the PK doseresponse curve; removal of RF reduced this enhancement, indicating that $R F$ interfered with the measurement of PK + PPK by the ELISA. It is therefore necessary to remove RF for the estimation of immunoreactive 


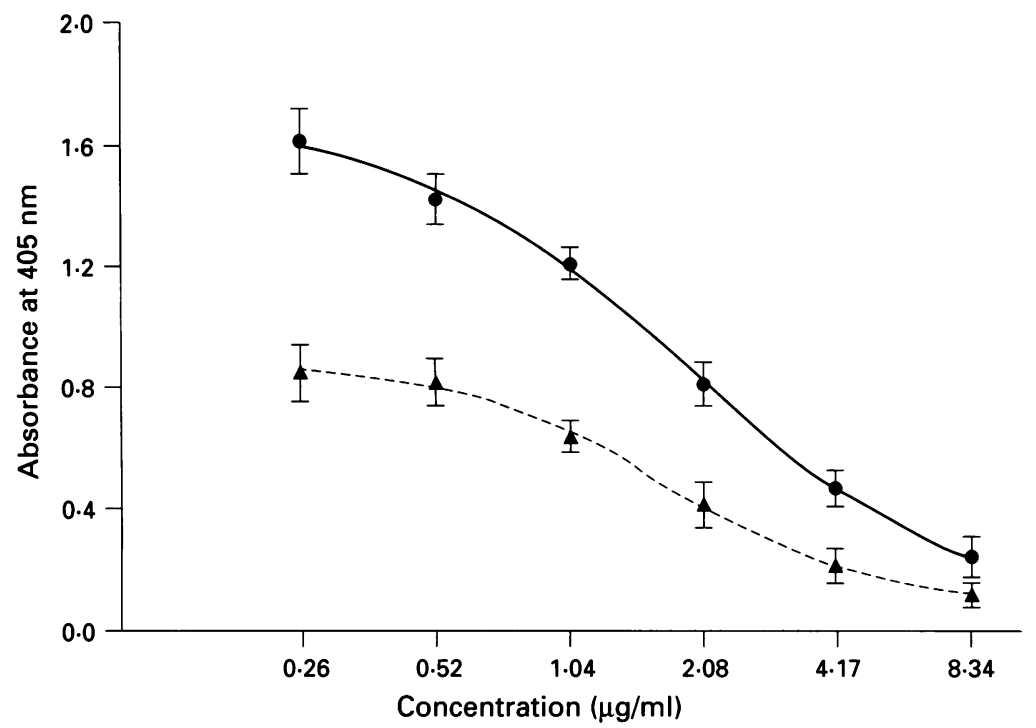

Figure 4 Concentration-dependent curve of immunoreactive $P K+P P K(O)$, and effect of $R A$ synovial fluid on it $(\mathbf{\Delta})$. Each experiment was performed three times in duplicate $(n=6)$.

PK + PPK. It may be argued that other factors were present in the SF which interfered with the immunoassay and which were not removed by pretreatment of SF with IgG Sepharose. Because PK was the primary coating molecule in the ELISA we expected minimal, if any, interference by inhibitors; none was observed. The results were further verified by demonstration that the PK + PPK immunoreactivity was removed by adsorption with anti-PK Sepharose.

Evidence for a proinflammatory role for kallikreins and kinins in arthritic joints has now accumulated, and a sequence of molecular events can be outlined. At the onset of inflammation, serum molecules and cells of the immune and phagocytic systems migrate into the inflamed joint tissue. The route of entry into the inflamed joint, of both the kallikreins and kininogens, may be by transudation or with the migrating neutrophil. ${ }^{216}$ The discovery of tissue kallikrein in neutrophil

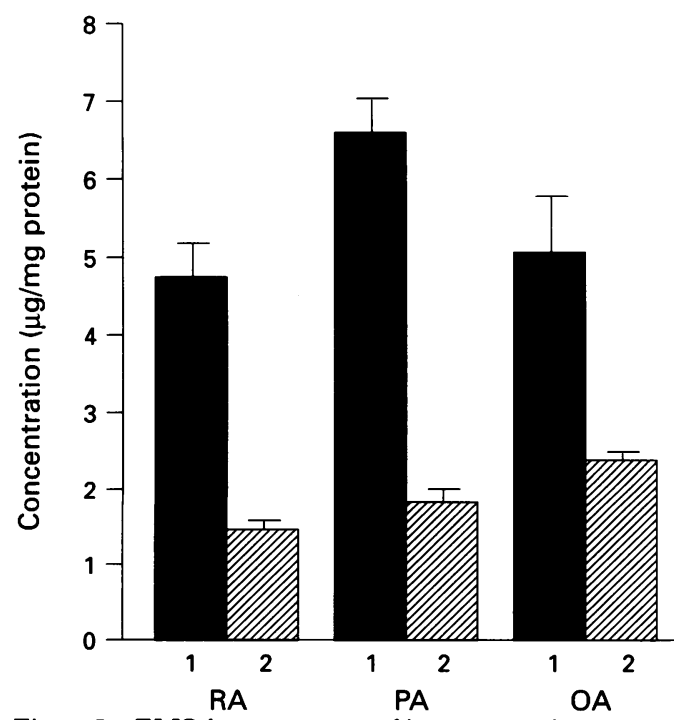

Figure 5 ELISA measurement of immunoreactive $P K+P P K$ in $R A, P A$, and $O A$ synovial fluids, before (1) and after (2) adsorption of the samples with anti-PK antibody linked to Sepharose. Each experiment was performed three times in duplicate $(n=6)$. granules, ${ }^{17}$ and the attachment of kininogens and PPK to the external surface of the neutrophil membrane ${ }^{1618}$ provide a novel mechanism for the delivery of the kinin forming enzymes and their endogenous substrates to inflamed joints. During episodes of acute inflammation within RA joints, neutrophils degranulate in response to immune complexes, ${ }^{19-21}$ resulting in the formation of kinin by the released tissue kallikrein. In contrast, conversion of PPK to its active form in the inflamed joint may be triggered through activation of Hageman factor by tissue matrix components, such as proteoglycans, urate crystals or pyrophosphates. ${ }^{22}$ The resulting PK is believed to cause significant conversion of latent collagenase to its active form in vitro, ${ }^{5}$ and this could be an important property of PK within the joint space.

Kinins formed by plasma and tissue kallikreins are considered to modulate pain and swelling in the inflamed joint, and these effects are probably effected through the bradykinin-1 (BK-1) receptor. ${ }^{23}$ In addition, kinins are known to release transmitters from nerve terminals (substance $P$ ), stimulate the synthesis of cytokines (interleukin-1, tumour necrosis factor), induce the formation of prostaglandins and leukotrienes by activating phospholipase $\alpha_{2}$, and release endothelium derived relaxing factor (nitric oxide) from endothelial cells. ${ }^{1}$ Effective BK-1 antagonists may play a pivotal role in inhibiting the cascade of proinflammatory molecules formed in the inflamed joint, and therefore should be of considerable therapeutic value.

M M Rahman was supported by the World Health Organisation. KDB thanks the Foundation for Research Development (South Africa) for Core grant funding.

1 Bhoola K D, Figueroa C D, Worthy K. Bioregulation of kinins: kallikreins, kininogens, and kininases. Pharmacol kinins: kallikreins,

2 Bhoola K D, Elson C J, Dieppe P A. Kinins-key mediators in inflammatory arthritis. $\mathrm{Br} \mathcal{F}$ Rheumatol 1992; 31: 509-19.

3 Rahman M M, Worthy K, Elson C J, Fink E, Dieppe P A Bhoola $\mathrm{K}$ D. Inhibitor regulation of tissue kallikrein activity in the synovial fluid of patient with rheumatoid arthritis. Br $\mathcal{F}$ Rheumatol 1994; 33: 215-23.

4 Kellermeyer R W, Breckenridge R T. The inflammatory process in acute gouty arthritis. I. Activation of Hageman factor by sodium urate crystals. $\mathcal{F}$ Lab Clin Med $1965 ; 65$ 307-15.

5 Nagase $H$, Cawston T E, De Silva $M$, Barrett A J Identification of plasma kallikrein as an activator of laten collagenase in rheumatoid synovial fluid. Biochim Biophys Acta 1982; 702: 133-42.

6 Suzuki M, Ito A, Mori Y, Hayashi Y, Matsuta K. Kallikrein in synovial fluid with rheumatoid arthritis. Biochem Med Metab Biol 1987; 37: 177-83.

7 Harpel P C, Mosesson M W, Cooper N R. Studies on the structure and function of $\alpha_{2}$-macroglobulin and C1-inactivator. In: Reich E, Rifkin D B, Shaw E, eds. Proteases and biological control. New York: Cold Spring Harbor Laboratory, $1975 ; 387$

8 Dyce B J, Wong T, Adham N, Mehl J, Haveback B J. Human plasma kallikrein esterase associated with $\alpha_{2}$-macroglobulin binding protein [abstract]. Clin Res $\alpha_{2}$-macroglobulin

9 Barrett A J. Inhibitors of various specificities. $\alpha_{2}$-Macroglobulin. Methods Enzymol 1981; 80: 737-54.

10 Fisher C A, Schmaier A H, Addonizio V P, Colman R W. Assay of prekallikrein in human plasma: comparison of amidolytic, esterolytic, coagulation and immunochemical assay. Blood 1982; 59: 963-70.

11 De La Cadena R A, Scott C F, Colman R W. Evaluation of a microassay for human plasma prekallikrein. $\mathfrak{f} \mathrm{Lab}$ Clin Med 1987; 109: 601-7.

12 Birk Y. Proteinase inhibitors from plant sources. Methods Enzymol 1976; XLV/B: 695-7.

13 Bradford $M M$. A rapid and sensitive method for quantification of microgram quantity of protein utilising the principal of protein dye binding. Anal Biochem 1976; 72: $248-54$. 
14 Bhoola K D, McNichol M W, Oliver S, Foran J. Changes in salivary enzymes in patients with sarcoidosis. $N$ Engl 877-9.

15 Oza N B, Schartz J H, Goud M D, Levinsky N G. Antibody that recognizes total human urinary kallikrein: radioimmunological determination of inactive kallikrein f Immunol 1981; 126: 2361-4.

16 Henderson L M, Figueroa C D, Müller-Esterl W, Bhoola K D. Assembly of contact phase factors on the surface of the human neutrophil membrane. Blood 1994 84: 474-82.

17 Figueroa C D, MacIver A G, Bhoola K D. Identification of a tissue kallikrein in human polymorphonuclear leukocytes. Br f Haematol 1989; 72: 321-8.

18 Figueroa C D, Henderson L M, Colman R W, De La Cadena R A, Müller-Esterl W, Bhoola $K$ D. ImmunoCadena $\mathrm{R} \mathrm{A}$, Mulle visualisation 79: $754-9$.
19 Dularey B, Dieppe P A, Elson C J. Depressed degranulation response of synovial fluid polymorphonuclear leukocytes from patients with rheumatoid arthritis to IgG aggregates. from patients with rheumatoid arthritis to IgG aggregates. Clin Exp Immunol 1990; 79: 195-201. $\mathrm{W}$. Activation of 20 Nurcombe $\mathrm{H}$, Bucknall, Edwards $\mathrm{S}$ W. Activation of neutrophil myeloperoxidase- $\mathrm{H}_{2} \mathrm{O}_{2}$ system by synovial fluid isolated from patients with

21 Elson C J, Thompson S J, Westacott C I, Bhoola K D Dieppe P A. Processes in rheumatoid arthritis and pristane induced arthritis: agalactosyl IgG and heat shock proteins. Eur $\mathcal{F}$ Rheumatol Inflamm 1993; 13: 9-19.

22 Kaplan A P, Reddigari S, Silverberg M. Assessment of the plasma kinin-forming pathways in allergic diseases. In: Fritz H, Schmidt I, Dietz G, eds. The kallikrein-kinin system in health and disease. Braunschweig, Germany: system in health and disease.

23 Bhoola K D, Dieppe P A. Kinins: inflammation-signalling peptides in joint disease. Eur $\mathcal{F}$ Rheumatol Inflamm 1991; 11: $66-75$. 